\title{
AARP Alaska
}

\section{VITAL VOICES}

Issues That Impact Alaska Adults Age 45 and Older August, 2020

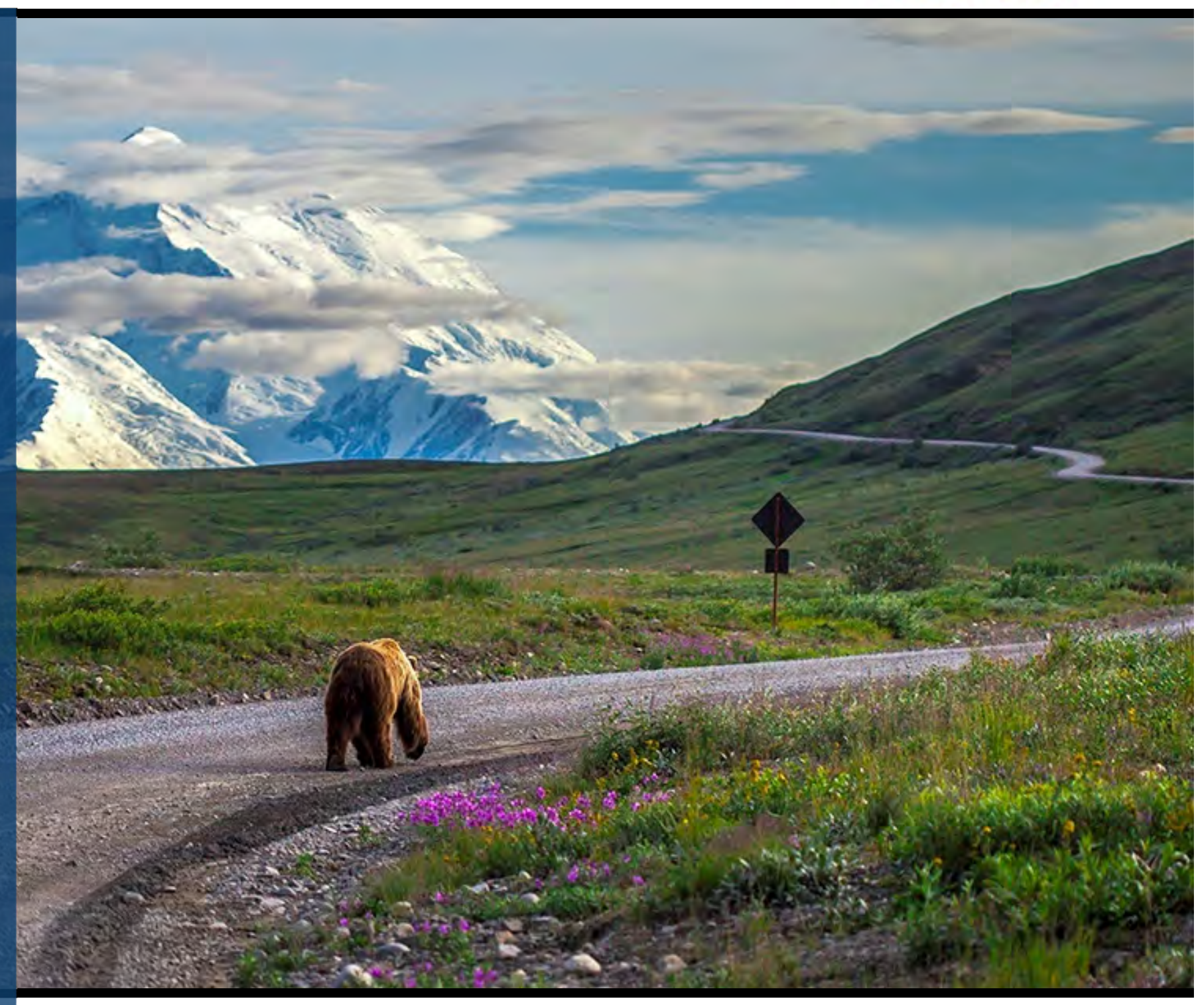




\section{TABLE OF CONTENTS}

Introduction to Vital Voices Surveys

3

Health Questions

4

Wealth Questions

Self Questions

17

Methodology

21

About AARP

23

Contact

24

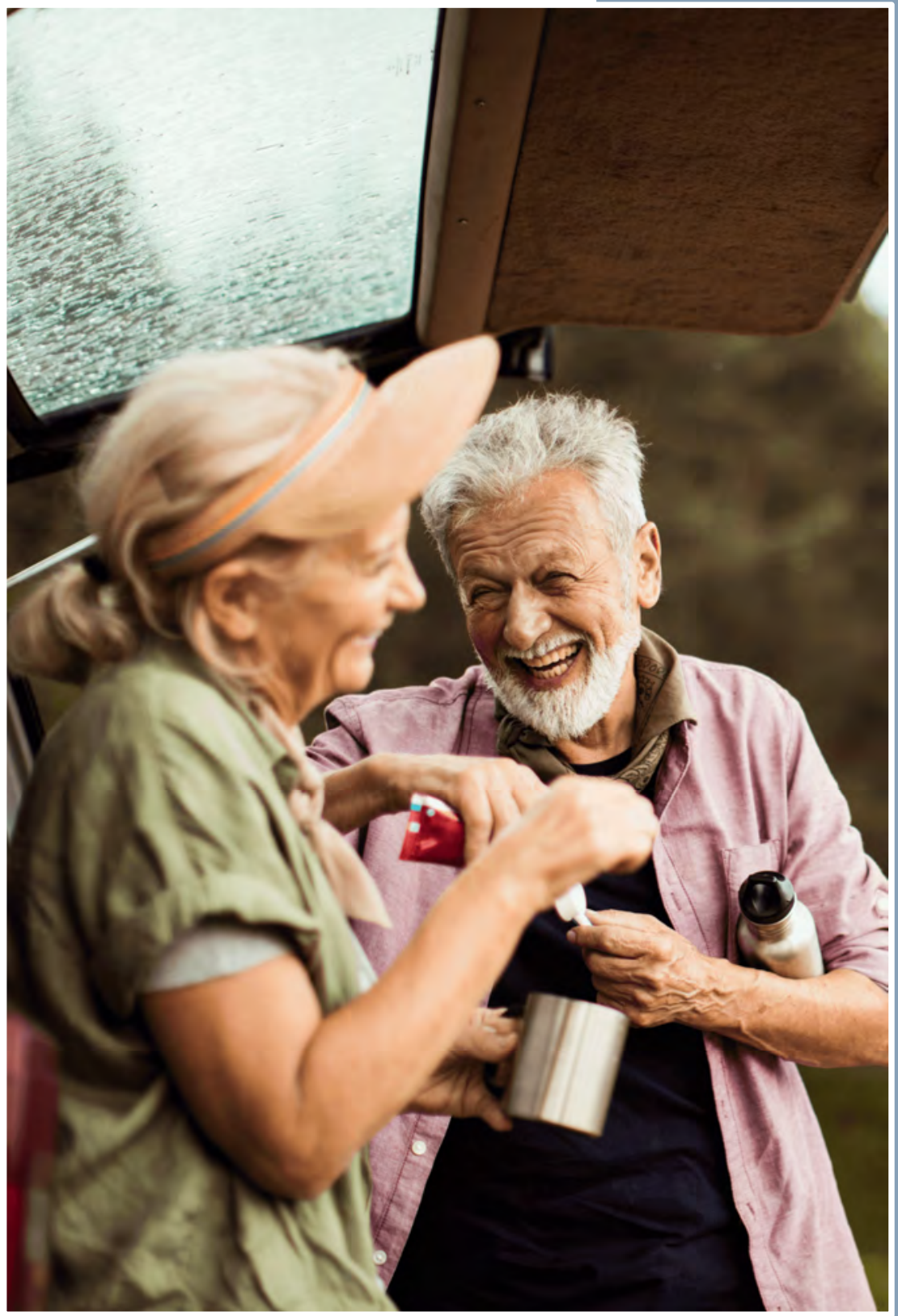




\section{INTRODUCTION}

There are currently about 117 million Americans who are 50 and older; this number will grow to 157 million by 2050. The 50 and older population is and will continue to be an essential contributor to American society. Understanding the needs and opinions of older Americans is critical to ensuring they live longer and healthier lives.

Vital Voices is a new and exciting program of research undertaken by AARP. Through this research program, we are launching a new initiative that will deliver critical, current, and state-specific data to 53 states on a rolling three-year schedule between 2019 and 2021. We are making this data available to the public to assist with the development of programs, products, and policies for older adults. This data will allow those in leadership positions to:

Predict the need for a specific program or interest in a particular issue. Enhance program and product innovation and development.

Track issues and attitudes over time to assess shifts in public opinion. - Take action on critical advocacy issues.

Never before has AARP launched a research program of this size and with this much promise. We give it to you, hoping that it will significantly impact the work you do.

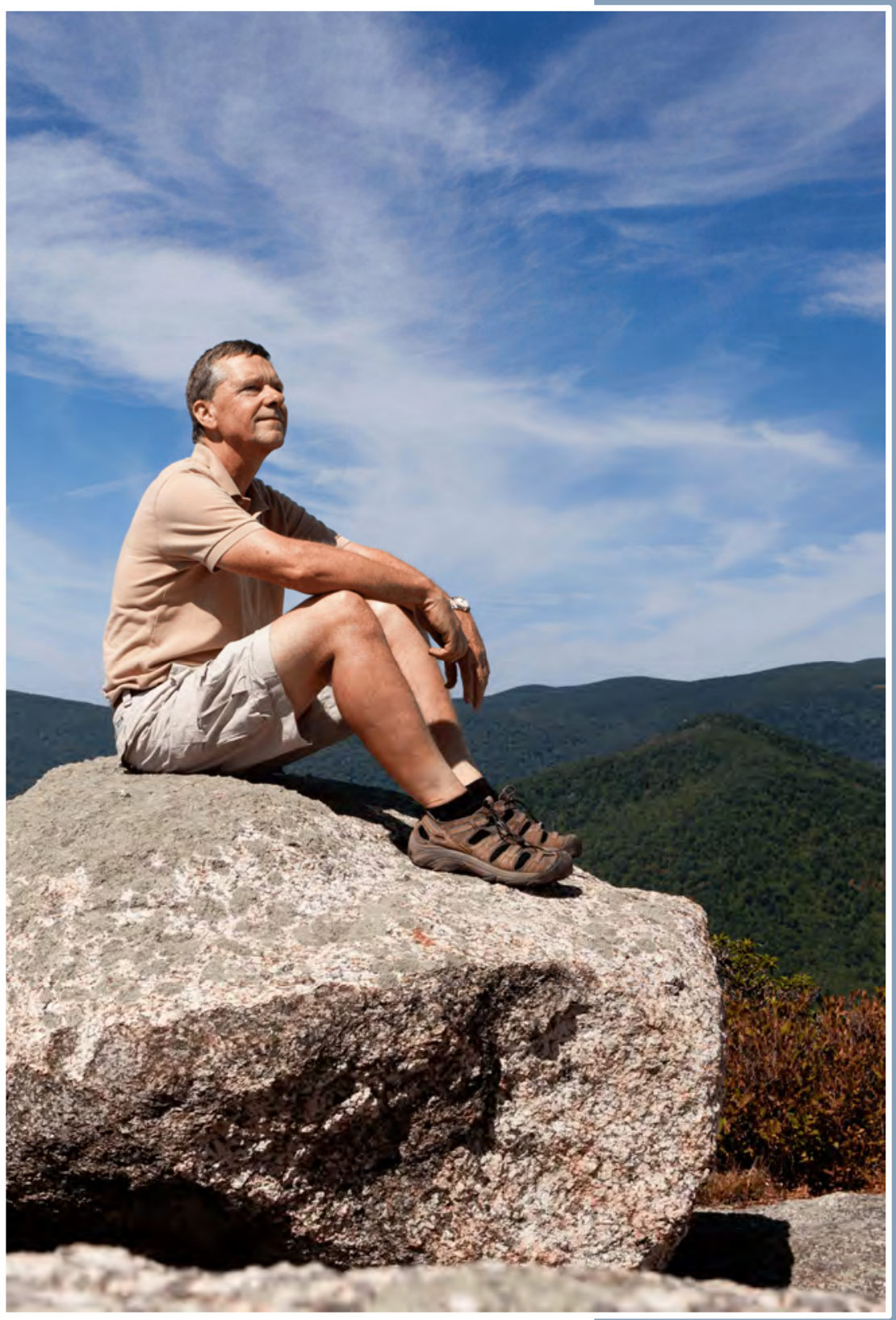




\section{Survey Results for Alaska- Health Questions}

Issues That Impact Alaska Adults Age 45 and Older

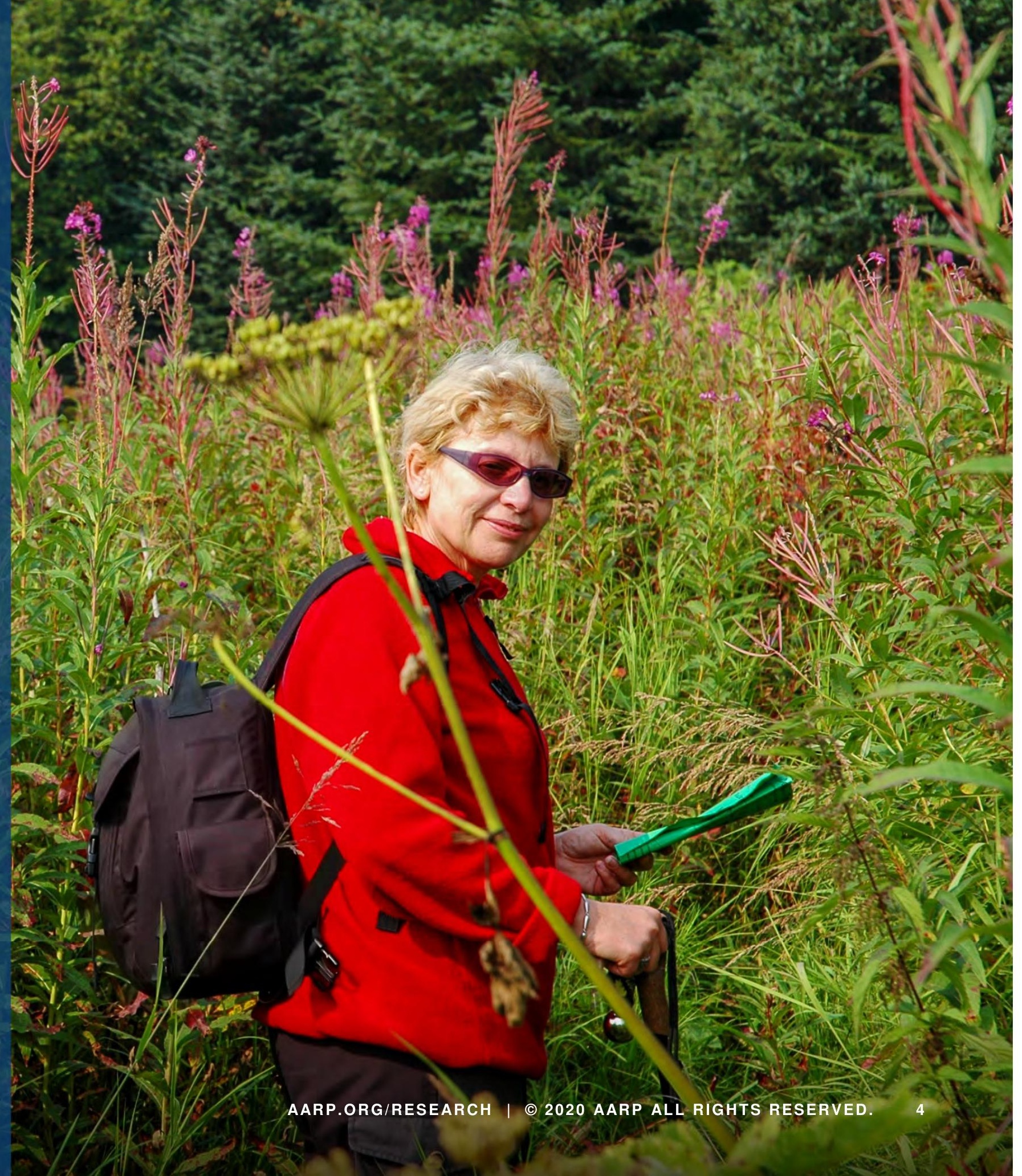




\section{ISSUES OF IMPORTANCE}

Alaska residents age 45+ think many healthcare issues are important, with staying mentally sharp and physically healthy topping the list.

\section{Important Healthcare Issues}

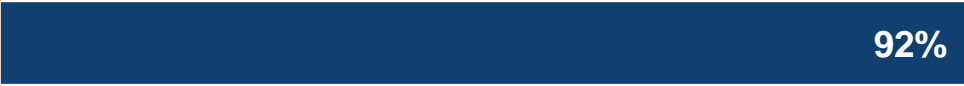

Staying physically healthy

$92 \%$

Having adequate health insurance coverage

Developing or maintaining healthy behaviors
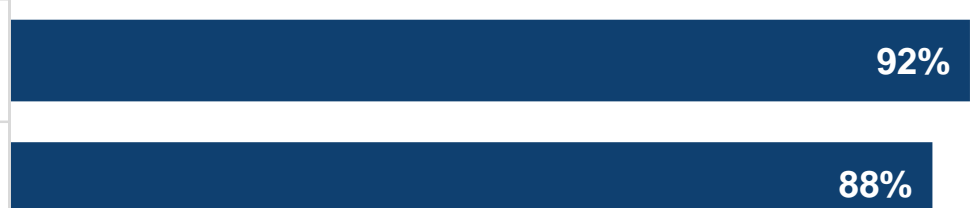

Having Medicare benefits available to you in the future

Paying for healthcare expenses 


\section{HEALTHCARE AND WELLNESS ISSUES}

Maintaining brain health is extremely important or very important to nine-in-ten (91\%) Alaska residents age 45+.

Healthcare and Wellness Issues of Importance

\section{Maintaining brain health}

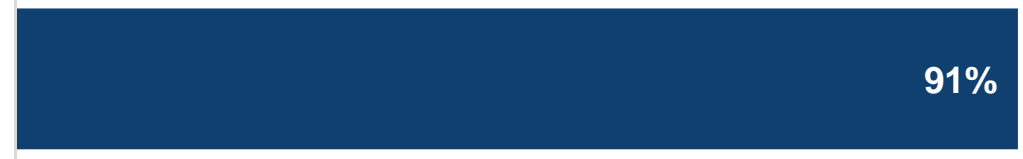

Maintaining a healthy diet

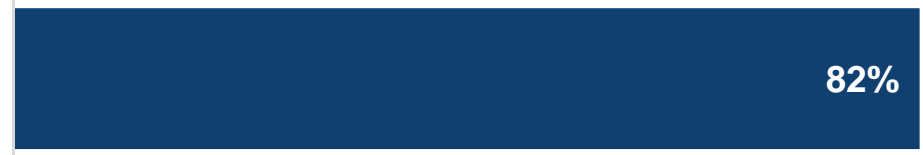

Getting enough sleep

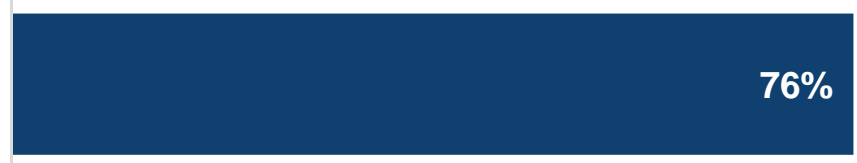

Reducing stress

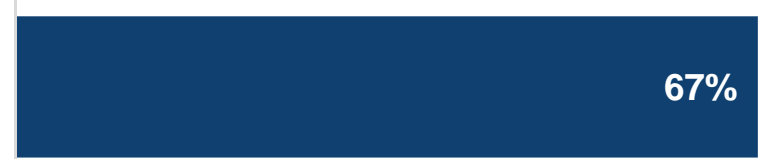

HC2. How important are each of the following to you, personally? (Percent 'extremely important' or 'very important') ( $n=706)$ 


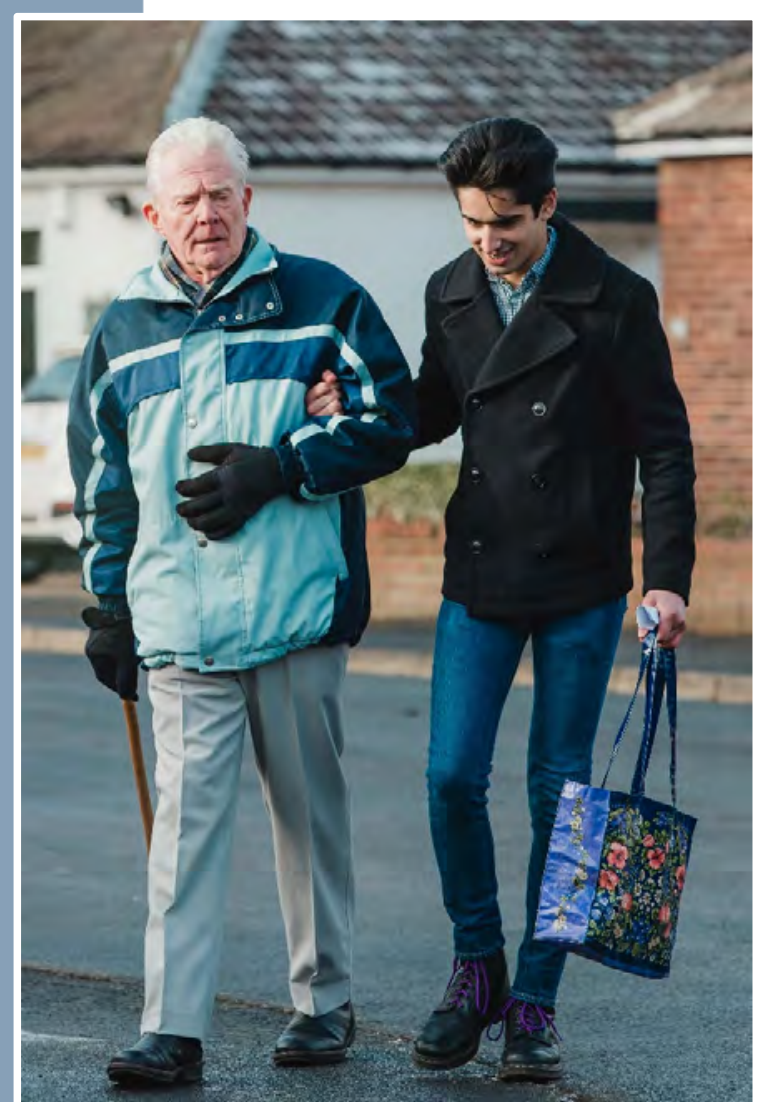

CARE1. Are you currently providing unpaid help to a relative or friend 18 years or older to help them take care of themselves? This would include doing things for them such as grocery shopping, providing transportation, managing finances, arranging for healthcare or other services, or preparing meals. $(n=706)$

\section{CAREGIVING ISSUES}

Three-in-ten (31\%) of Alaska residents age 45+ are currently providing unpaid help to an adult relative or friend.

\section{Percent Providing Unpaid Adult Care}

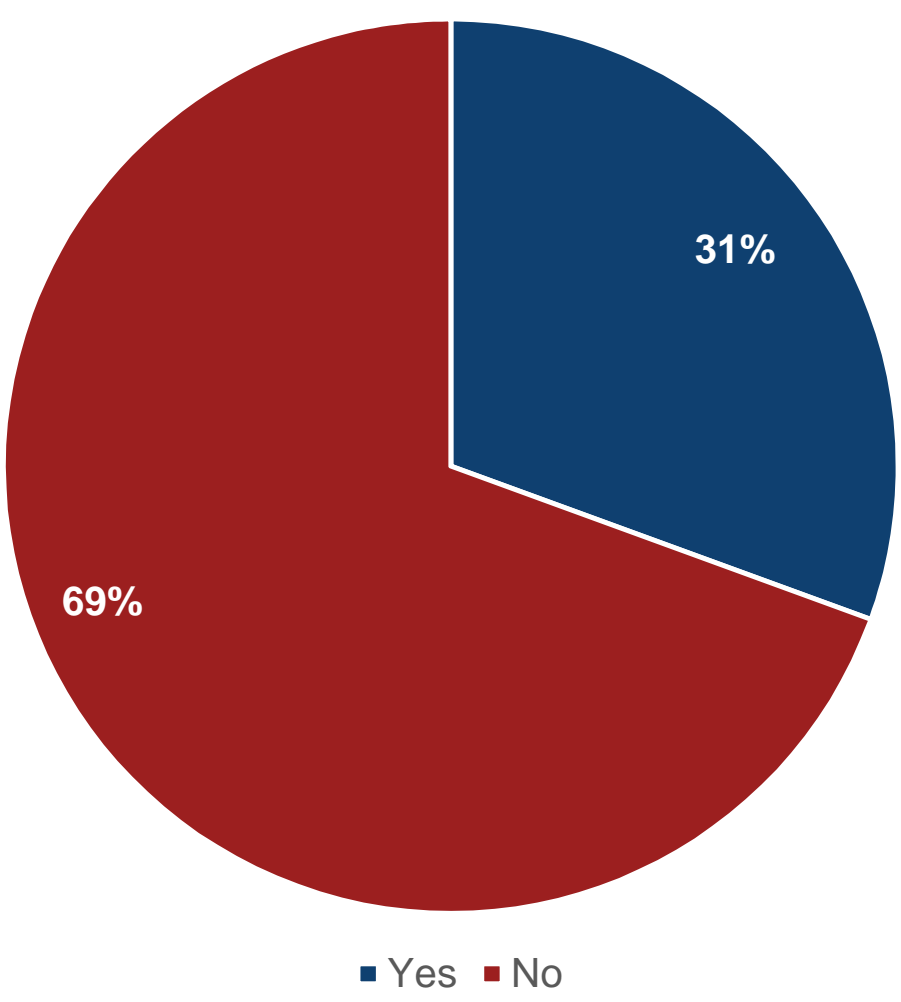




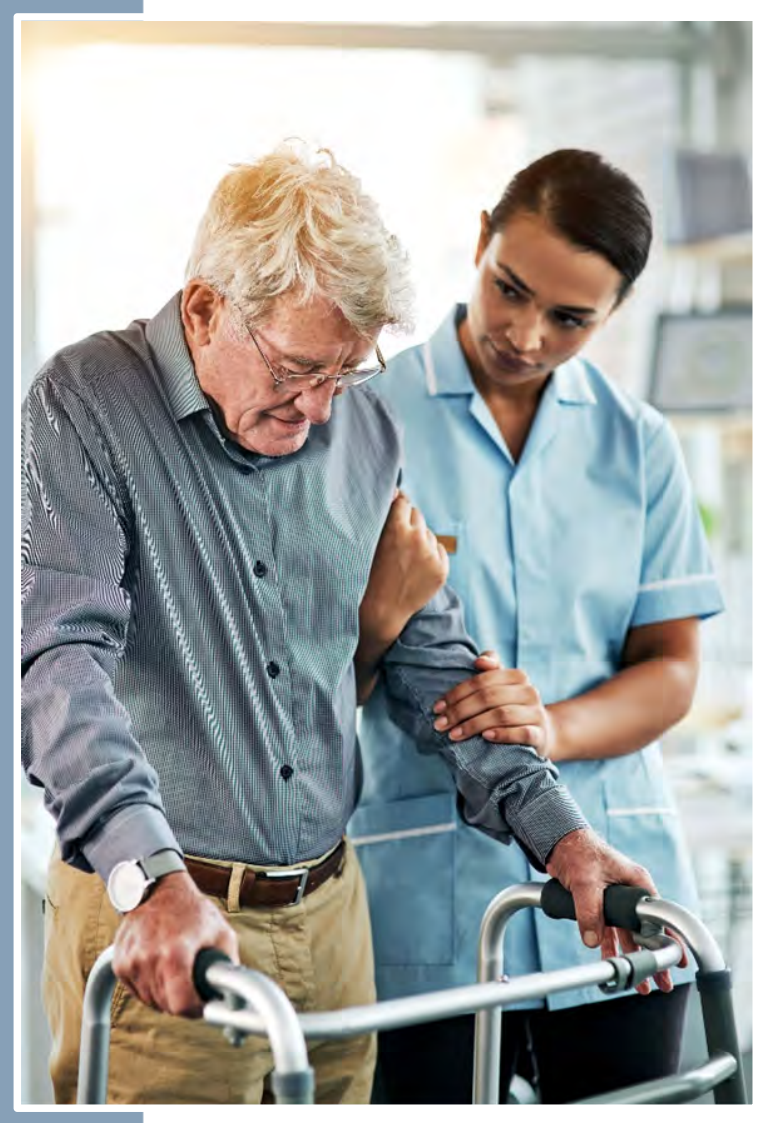

CARE1_A. Have you ever provided this type of unpaid help in the past? $(n=491)$

\section{CAREGIVING ISSUES}

Nearly half $(47 \%)$ of Alaska residents age $45+$ who are not currently unpaid caregivers have provided this type of care in the past.

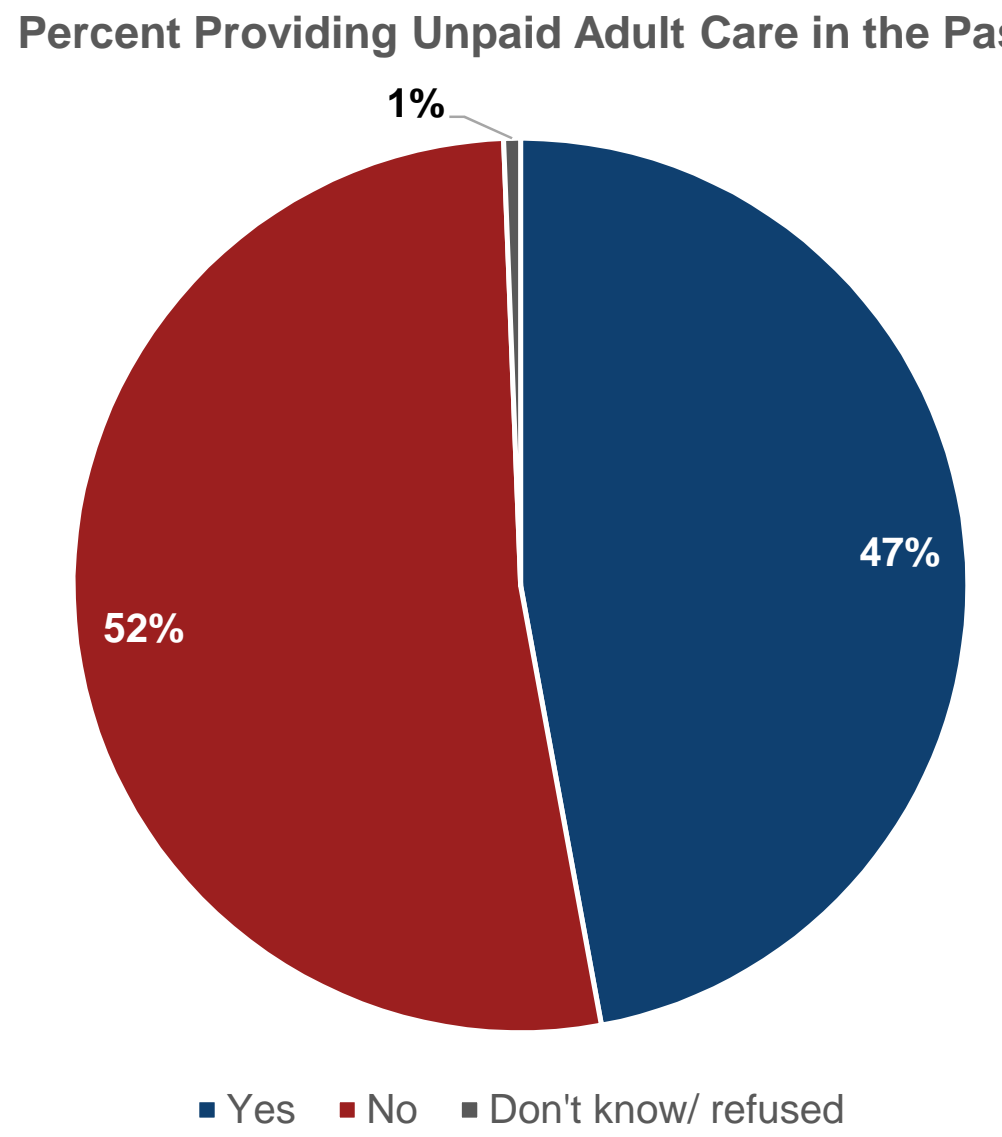




\section{CAREGIVING ISSUES}

\section{Alaska residents age 45+ identified many types of assistance as helpful for caregivers, including information about available resources for caregivers $(58 \%)$ and respite care services $(57 \%)$.}

\section{Most Helpful Caregiving Support/ Assistance}

Information about available resources for caregivers in your community

Respite care or breaks from caregiving responsibilities

$57 \%$

Assistance with providing transportation to medical appointments

Assistance with understanding how to manage medications

Assistance with providing transportation in general

Assistance with managing household chores

$44 \%$

Assistance with providing meals

$41 \%$

Connecting with other caregivers in similar situations

CARE29. In your opinion, as a current caregiver/someone who may provide care in the future, how helpful would the following types of caregiving support be to you? (Percent 'extremely helpful' or 'very helpful') $(n=706)$ 


\section{PRESCRIPTION DRUGS}

Monthly out-of-pocket spending on prescription drugs varies among Alaska residents age $45+$, with two-thirds (66\%) spending less than $\$ 50$ per month.

\section{Annual Spend on Prescription Medications*}

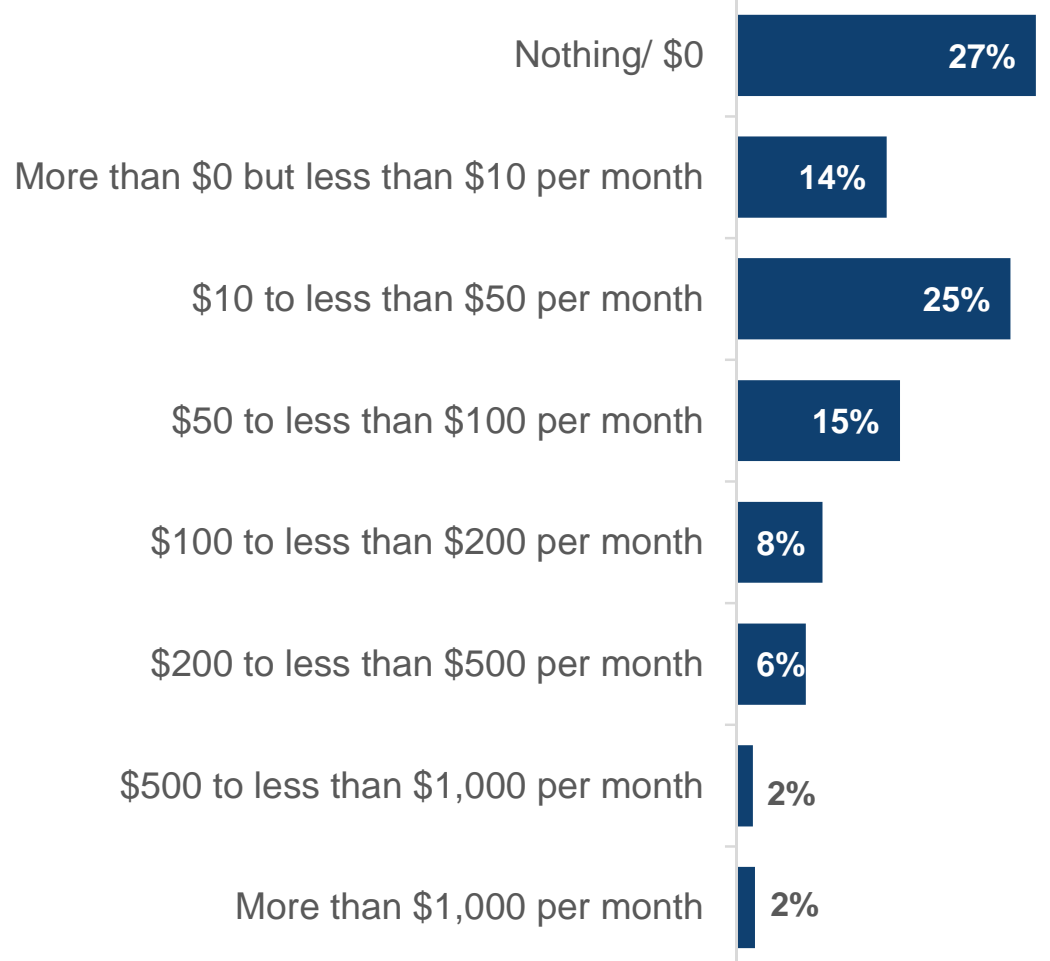

PER3. In the past 12 months, approximately how much have you spent out of your own pocket for prescription drugs? ( $\mathrm{n}=706$ )

*Not equal to one-hundred percent due to removal of small cells; see annotation for all categories 


\section{Survey Results}

for Alaska-

\section{Wealth}

\section{Questions}

Issues That Impact Alaska Adults Age 45 and Older

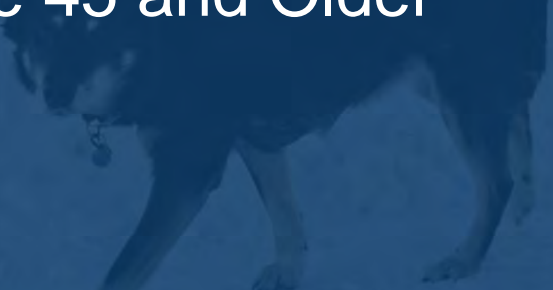




\section{ISSUES OF IMPORTANCE}

\section{Alaska residents age 45+ think many economic issues are important, particularly those related to retirement savings.}

Important Economic Issues

Having enough income or savings to retire

Protecting yourself against unfair financial practices

Having adequate Social Security benefits

Protecting yourself against consumer fraud

Having online security

Having good employment opportunities in your community

Being able to stop working for pay at the age you want

Having access to high-speed internet

Protection from age discrimination

Maintaining relevant job skills and experience

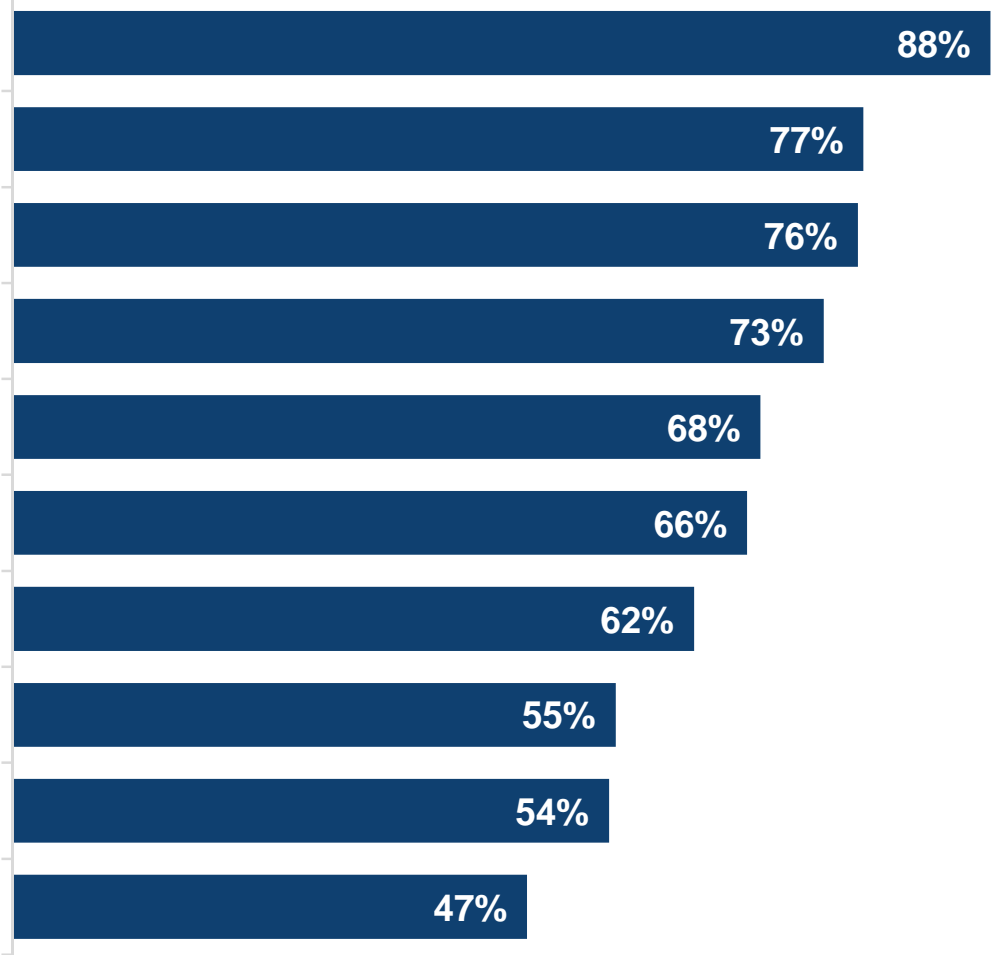




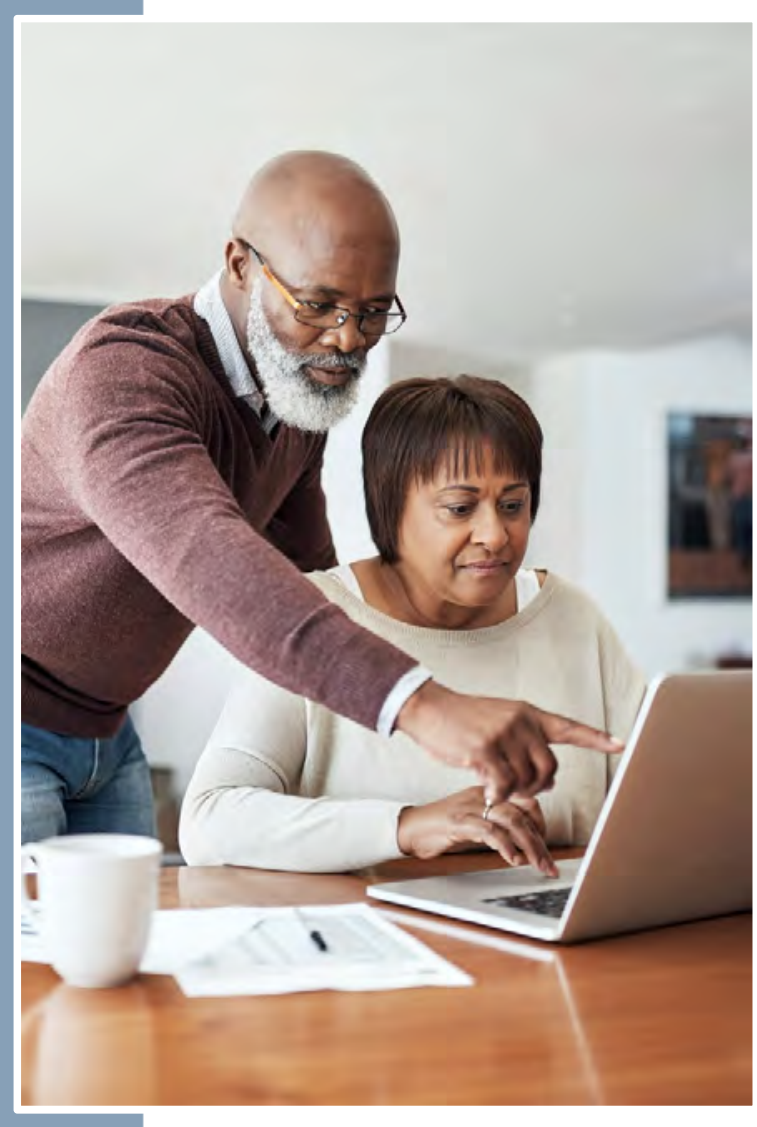

RET5. Given the amount of money you currently have saved, do you wish you had more money saved for your retirement years? $(n=706)$

\section{RETIREMENT ISSUES}

Nearly three-quarters (74\%) of Alaska residents age 45+ wish they had more money saved for their retirement years.

\section{Wish More Was Saved for Retirement}

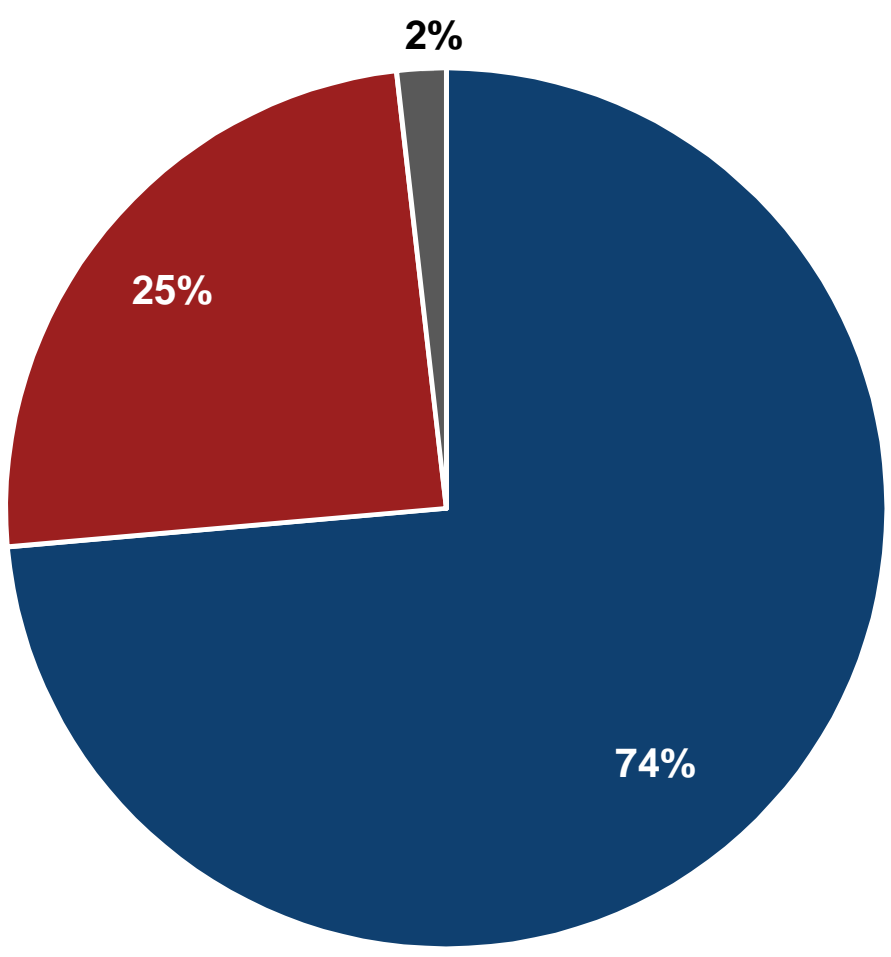

-Yes - No - Don't know/ refused 


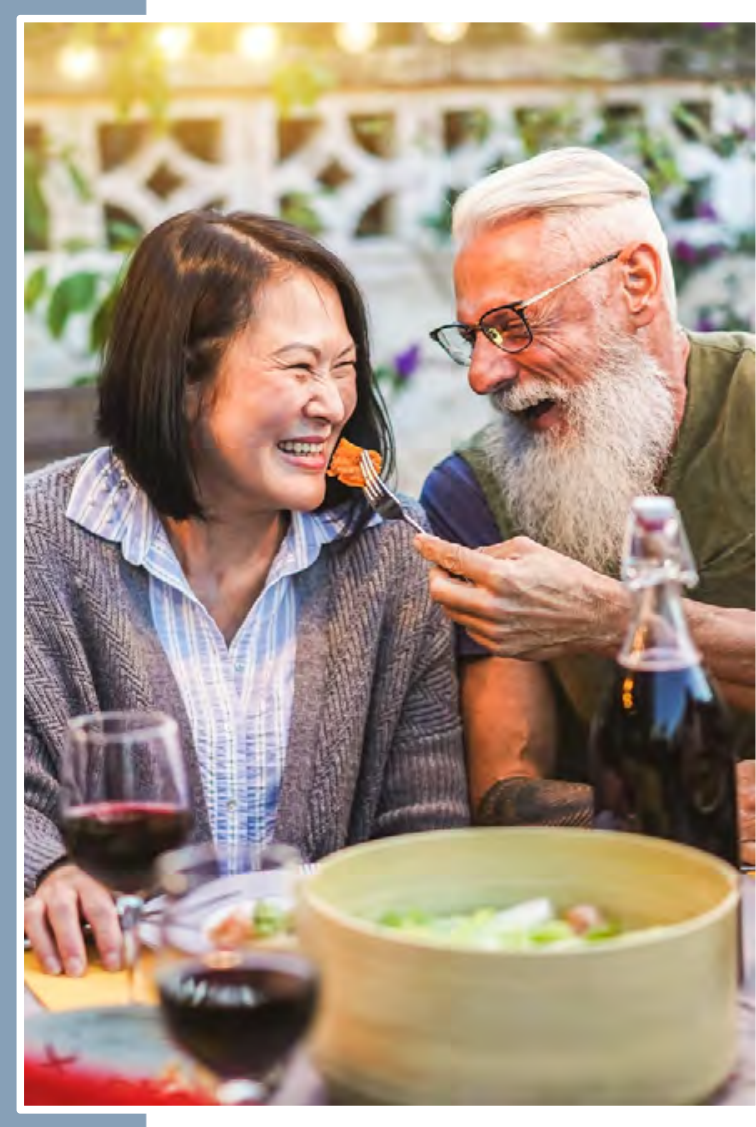

RET16. Do you plan on living

in Alaska during your retirement years full-time, part-time, or not at all? $(n=706)$

\section{RETIREMENT ISSUES}

Two-thirds (68\%) of Alaska residents age 45+ are currently living in Alaska full-time during retirement or are planning to do so in the future.

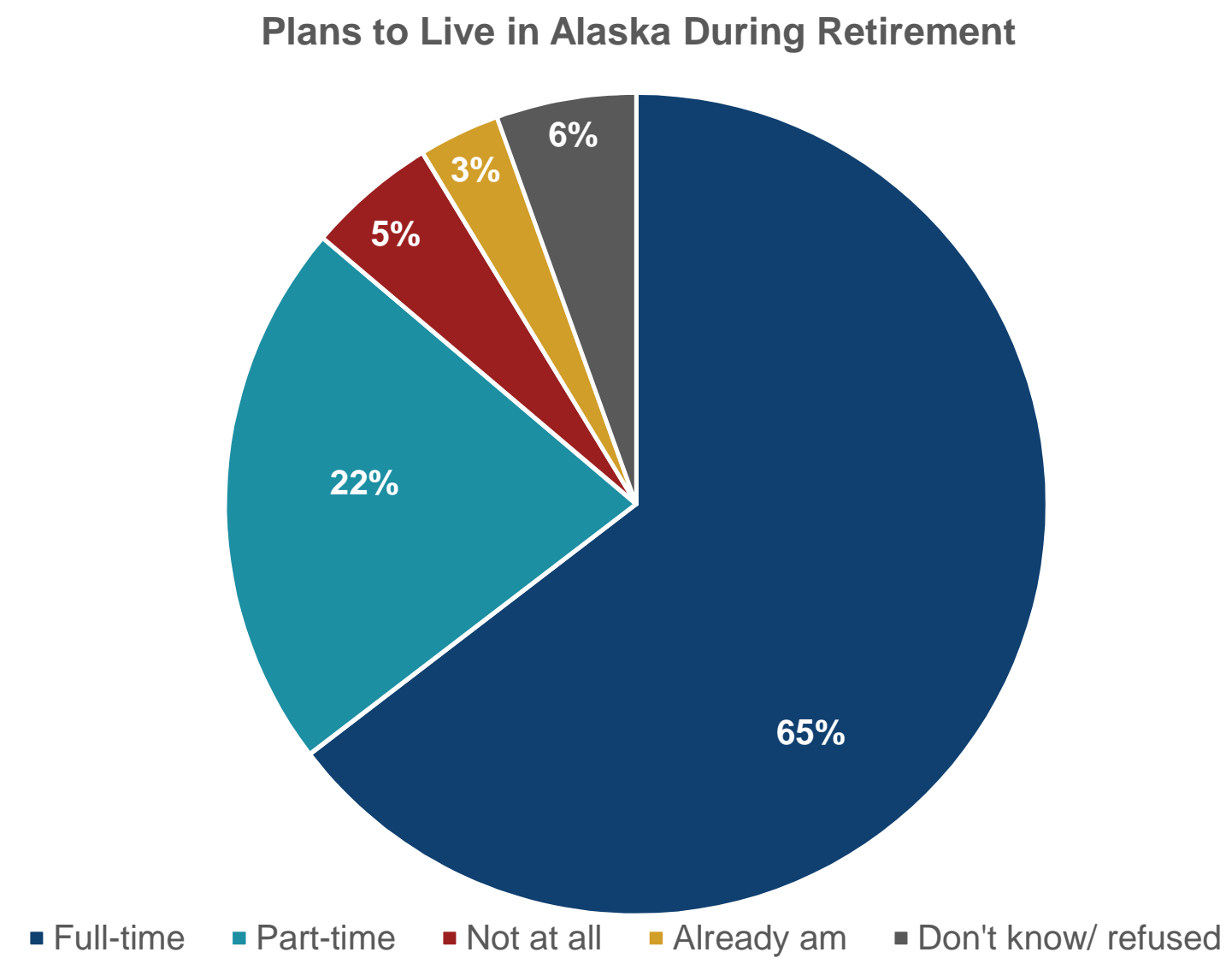




\section{FRAUD ISSUES}

Only half (52\%) of Alaska residents age $45+$ know how to freeze their credit with the three credit bureaus.

Aware of How to Freeze Credit

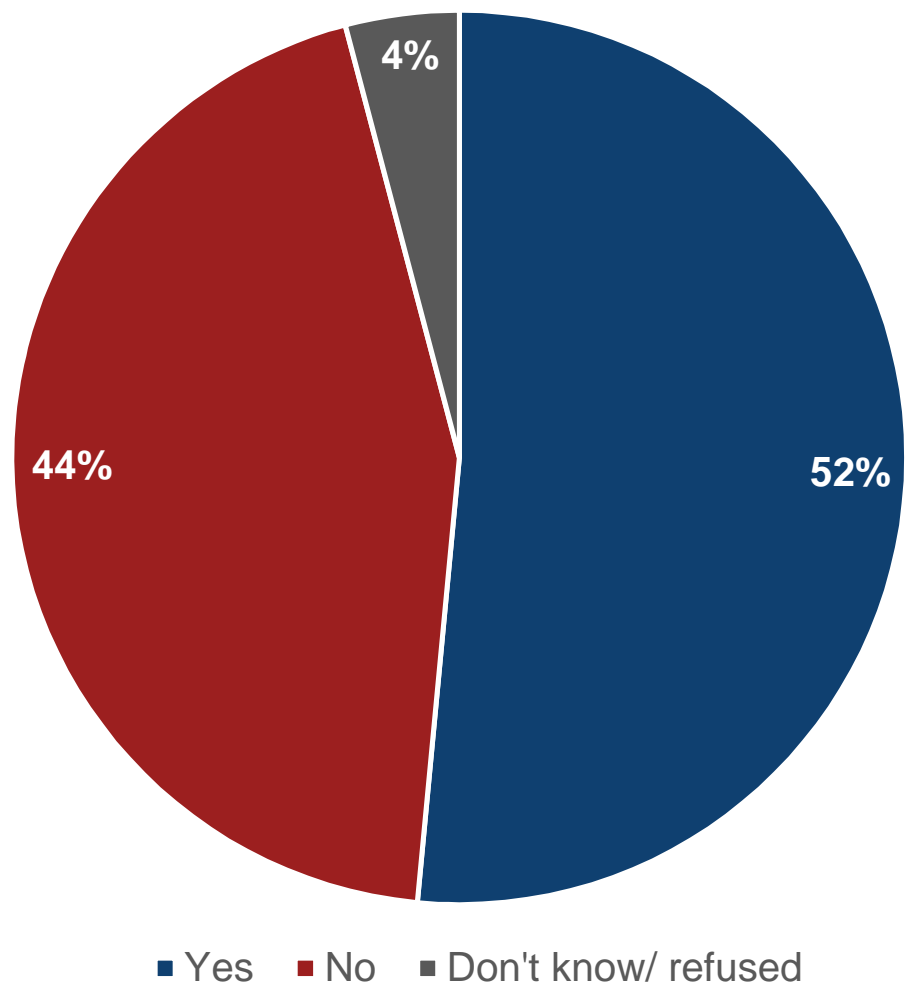

FRA23. Do you know how to freeze your credit with the three credit bureaus? ( $n=706)$ 


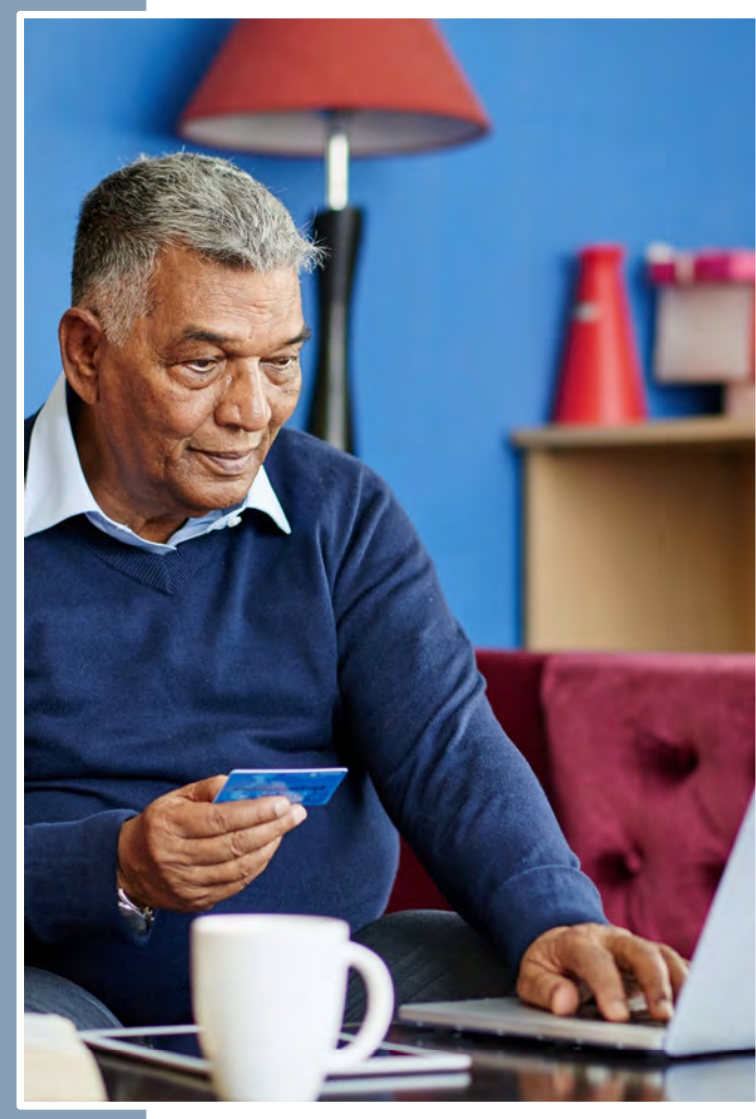

FRA3. Identity theft takes place when someone wrongfully obtains your identity and intends to use it, typically for economic gain. This may include

opening new credit accounts, such as credit cards, loans, or utilities in your name; purchasing merchandise or gift cards with your existing credit or debit cards; withdrawing cash from your account at an ATM; creating fake checks and cashing them against your account, or getting medical care or medications as if they were you. In the past 12 months, has this happened to you? $(n=706)$

\section{FRAUD ISSUES}

One-in-ten (10\%) Alaska residents age $45+$ have been a victim of identity theft in the past year.

Victim of Identity Theft in the Past 12 Months

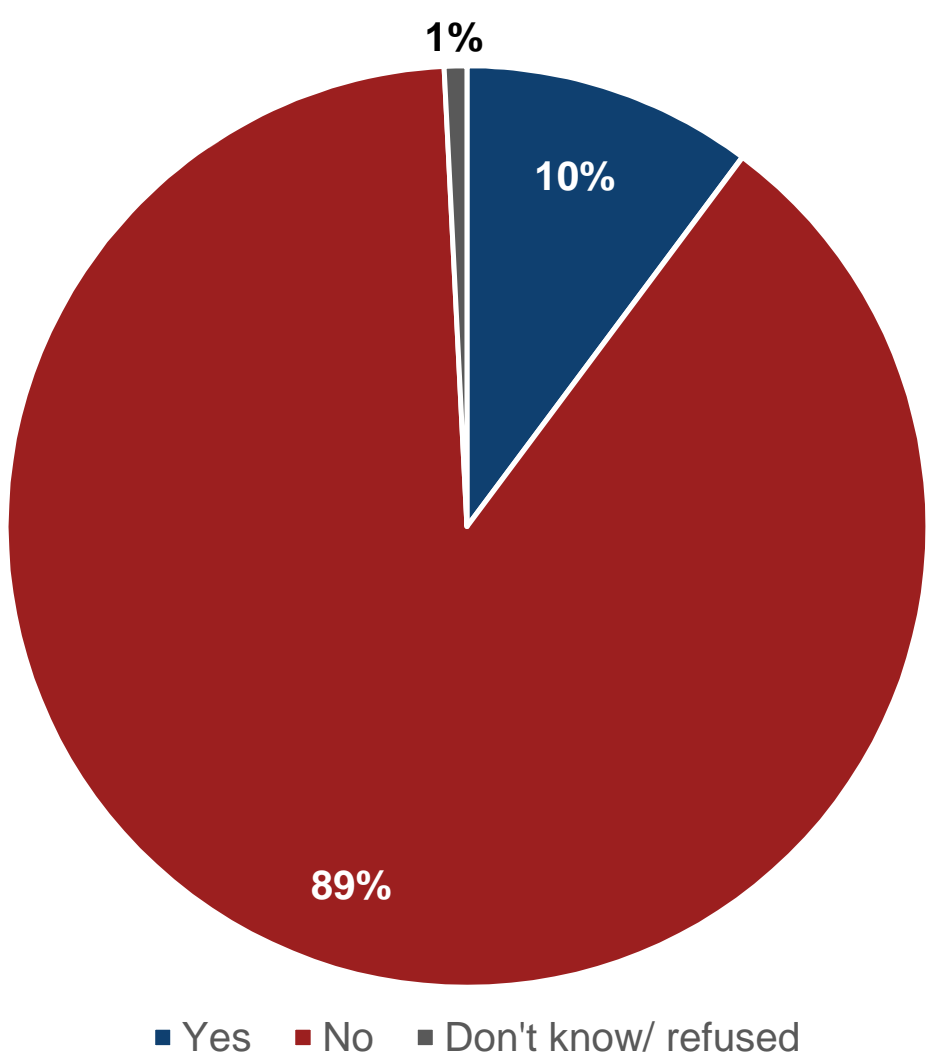




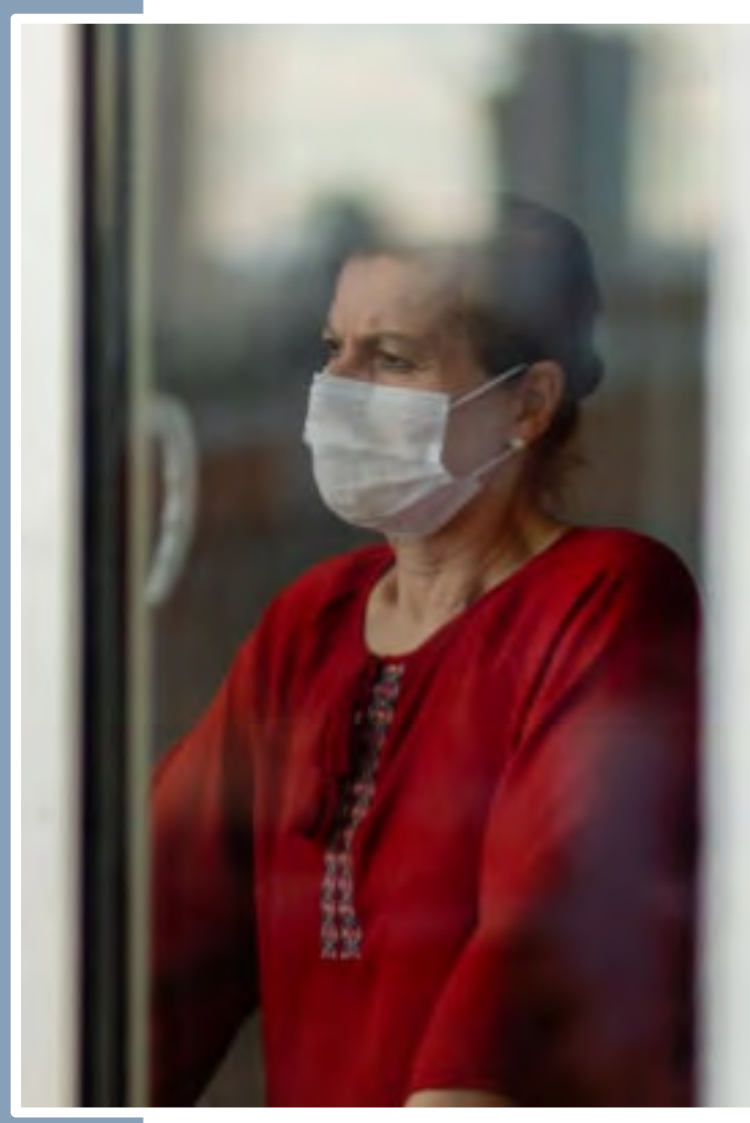

FP17. How concerned are you that the following issues affect your life in the next 6 months? (Percent 'extremely concerned' or 'very concerned') $(\mathrm{n}=687)$

\section{ATTITUDES ON AGING}

Nearly half $(49 \%)$ of Alaska residents age $45+$ are extremely or very concerned about staying healthy and safe from COVID-19 over the next 6 months.

Top Concerns in the Next 6 Months
Staying healthy and safe from COVID-19

Being isolated due to COVID-19

Afraid to access medical services due to COVID-19

Not having enough money for food/ utilities

Not being able to afford prescriptions

Not having enough money to pay rent/ mortgage

\section{$19 \%$}




\section{ISSUES OF IMPORTANCE}

Caring for a loved one is extremely or very important to a majority $(85 \%)$ of Alaska residents age $45+$.

\section{Important Independent Living Issues}

Caring for a loved one

Getting to the places you need to go independently

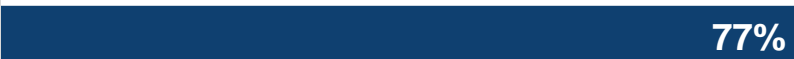

Having high quality long-term care in your community

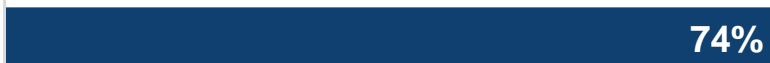

Staying in your own home as you get older

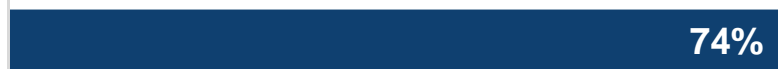

Having flexibility in your schedule for caregiving

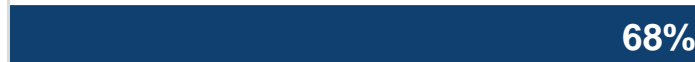

Having affordable housing options in your community

Improvements to AK's long-term care services

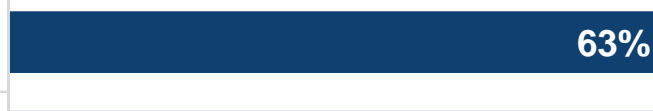

Staying in your community as you get older

Having paid time off for self-care or caregiving

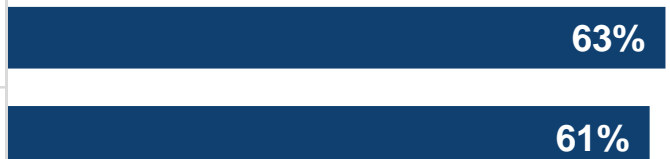

$54 \%$

11. For the following list of issues, please indicate how important each is to you personally. (Percent 'extremely important' or 'very important') ( $\mathrm{n}=706)$ 


\section{INDEPENDENT LIVING}

End of life or hospice services are extremely or very important to eight-in-ten (82\%) Alaska residents age $45+$, as a community feature for helping older adults live independently.

\section{Most Important Community Services for Independent Living}

End of life or hospice services

Well-trained certified home health care providers

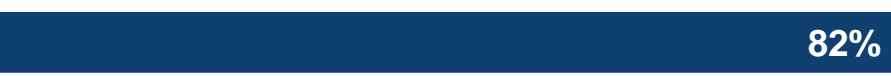

Visiting nurse services

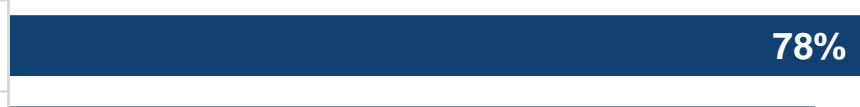

Special transportation services

An easy way for caregivers to get information and resources

Breaks for family caregivers

Senior or community centers

Chore or homemaker services

Congregate meals

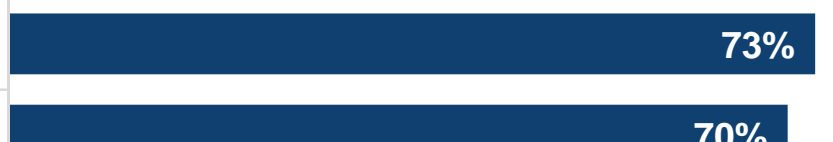

\section{$70 \%$}
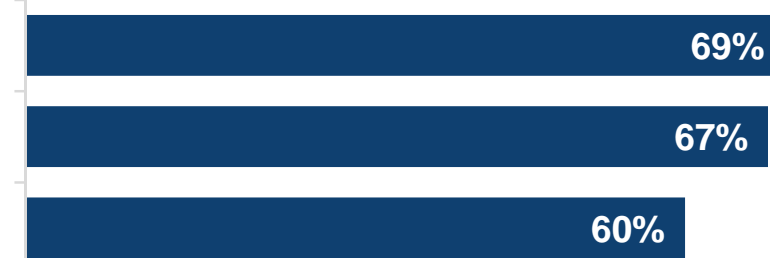

$60 \%$

Home delivered meals

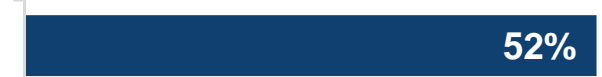

CARE40. How important is it to have the following services available in your community to help older adults live independently? (Percent 'extremely important' or 'very important') $(\mathrm{n}=706)$ 


\section{METHODOLOGY}

In August 2020, AARP engaged ANR Market

Research Consultants to conduct a

quantitative research study among Alaska residents age 45 and older. Topics included healthcare, the economy, financial issues, independent living, long-term care, caregiving, retirement issues.

\section{Interviews}

\section{Alaska Residents Age 45+}

\section{Fielded in August 2020}

ANR completed a total of 706 interviews (513 via landline telephone, 177 via cell phone, and 16 online). Respondents were screened to meet the following criteria:

- Age 45+

- Resident of Alaska

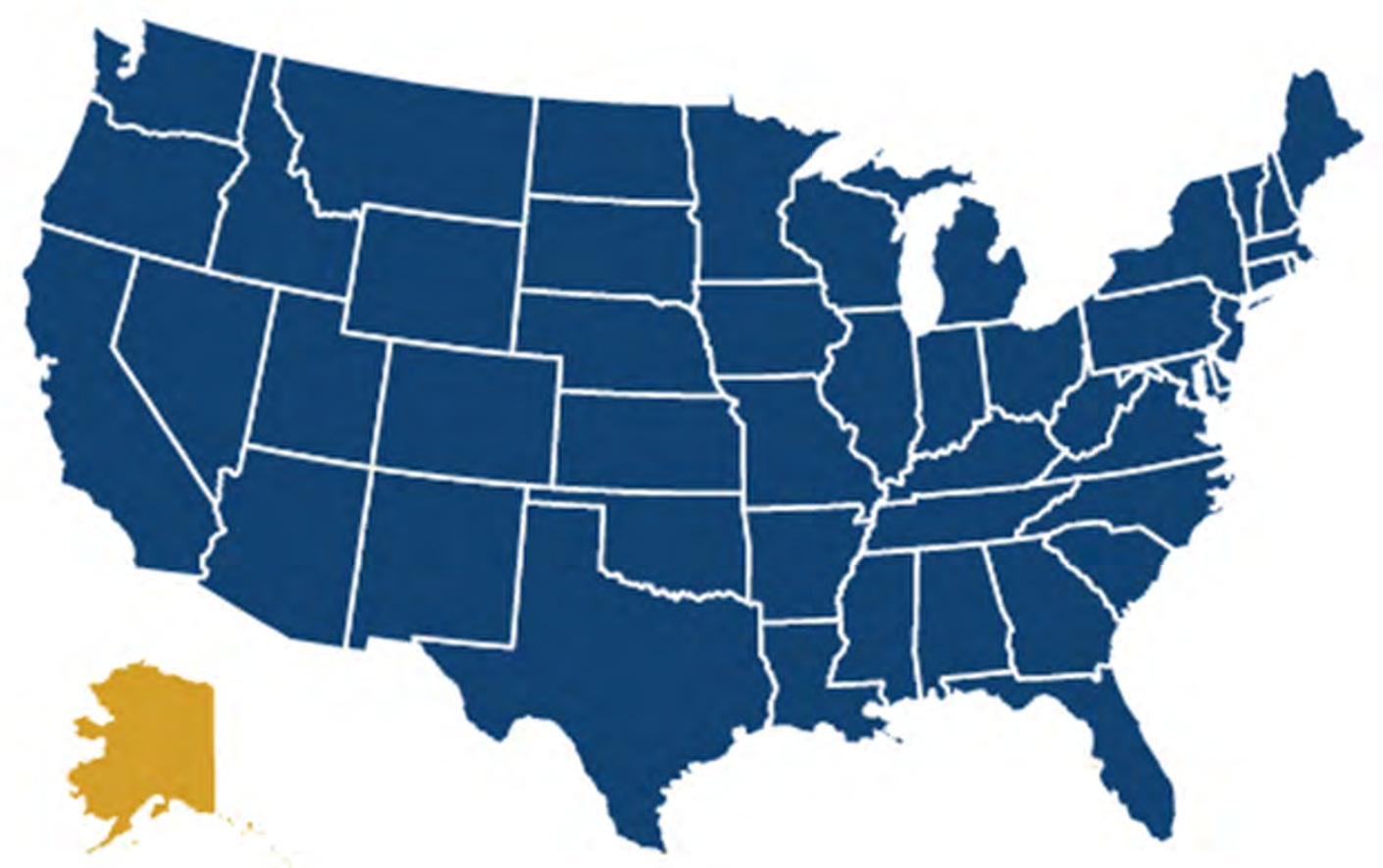

Alaska

Survey length averaged 20.1 minutes by telephone and 19.0 minutes online. 


\section{METHODOLOGY}

\section{Sampling Procedure}

Landline, cell phone, and online sampling were used for this research, with the telephone sample drawn randomly from a list of Alaska residents age 45 and older, purchased from Aristotle, and online sample provided by Fulcrum. A total of 32,408 records were utilized to achieve a sample of 706 respondents. The list of 258,218 residents of Alaska age 45 and older was randomly divided into 259 replicates of 1,000 records for telephone dialing. Initially, 20 replicates were released for calling, with additional replicates being opened as necessary. In all, 33 replicates representing a total of 32,408 resident records were dialed to complete the telephone portion of this study.

The total sample of 706 respondents yields a maximum statistical error of $\pm 3.7 \%$ at the $95 \%$ level of confidence. (This means that in 95 out of 100 samples of this size, the results obtained in the sample would be within \pm 3.7 percentage points of the results obtained had everyone in the population been interviewed.)

\section{Interview Methodology}

The survey was launched on August 19, 2020 and closed on August 27, 2020.

Telephone interviewing was active between 5:30 p.m. and 9:00 p.m., with some additional calling done between 10:00 a.m. and 4:00 p.m. If necessary, up to 8 call attempts per telephone number were made to reach an eligible respondent. All numbers were called at multiple times of the day as well as days of the week to maximize each resident's opportunity for inclusion in the study.

Percentages of some questions may exceed $100 \%$ due to rounding or the use of multiple response question formats.

All data have been weighted by age, gender, and race/ethnicity according to 2018 U.S. Census Bureau Current Population Survey (CPS) statistics for Alaska.

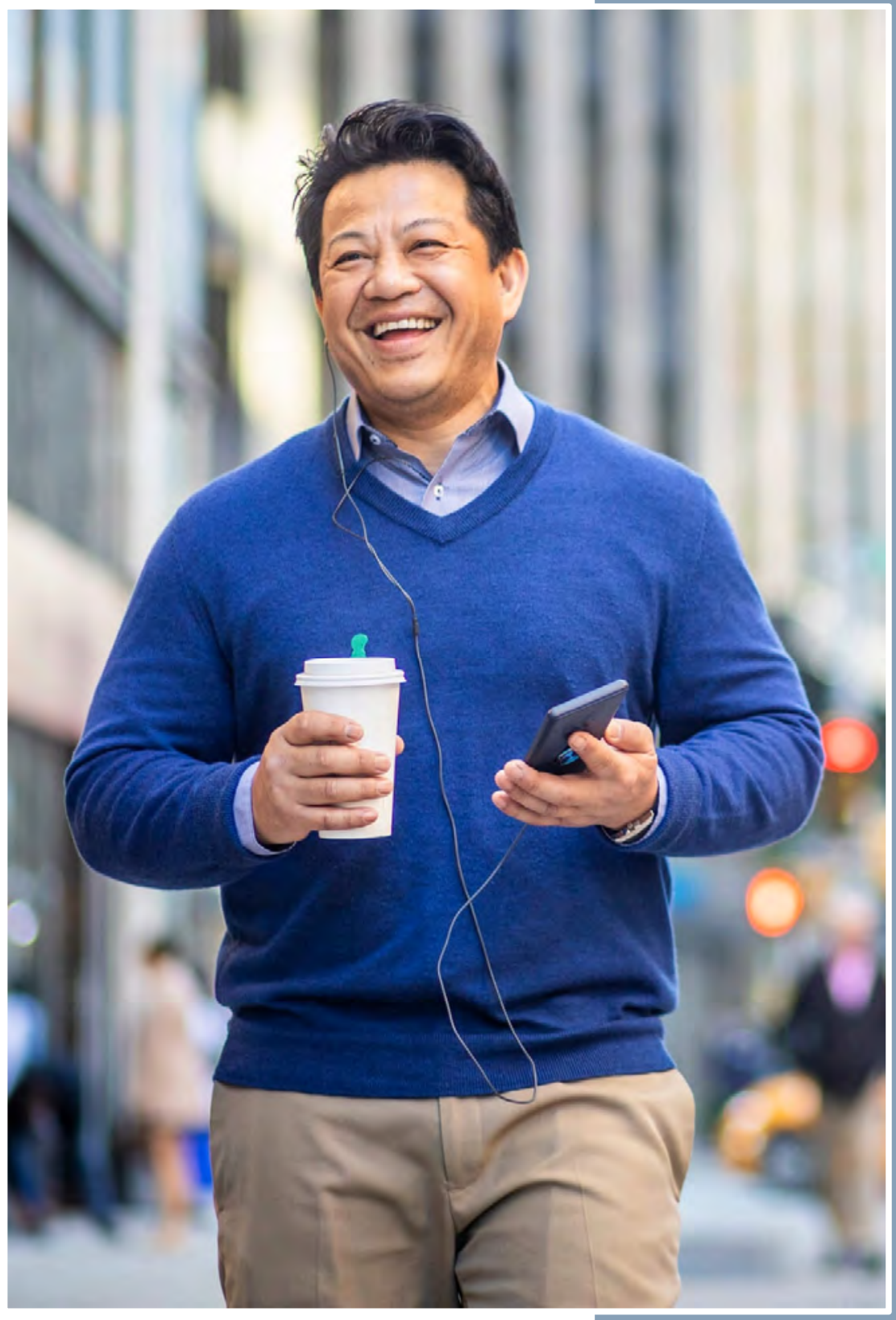




\section{ABOUT AARP}

AARP is the nation's largest nonprofit, nonpartisan organization dedicated to empowering Americans 50 and older to choose how they live as they age. With nearly 38 million members and offices in every state, the District of Columbia, Puerto Rico, and the U.S. Virgin Islands, AARP works to strengthen communities and advocate for what matters most to families with a focus on health security, financial stability and personal fulfillment. AARP also works for individuals in the marketplace by sparking new solutions and allowing carefully chosen, high-quality products and services to carry the AARP name. As a trusted source for news and information, AARP produces the nation's largest circulation publications, AARP The Magazine and AARP Bulletin. To learn more, visit www.aarp.org or follow @AARP and @AARPadvocates on social media.

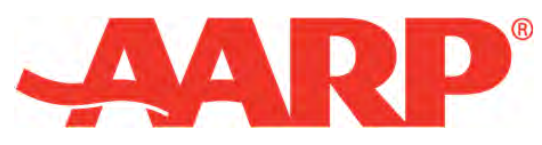

AARP.ORG/RESEARCH (C) 2020 AARP ALL RIGHTS RESERVED.

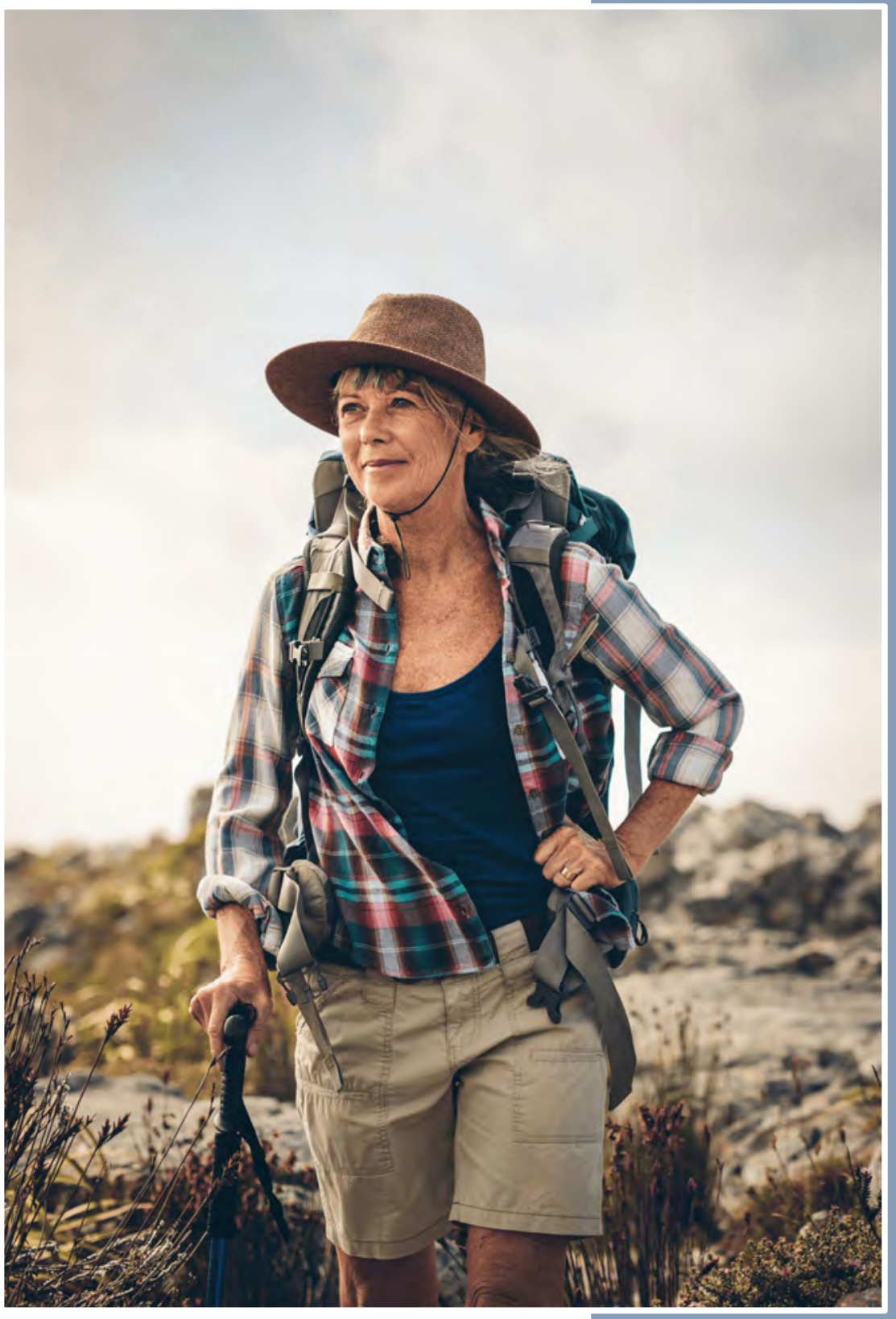

23 


\section{AARP}

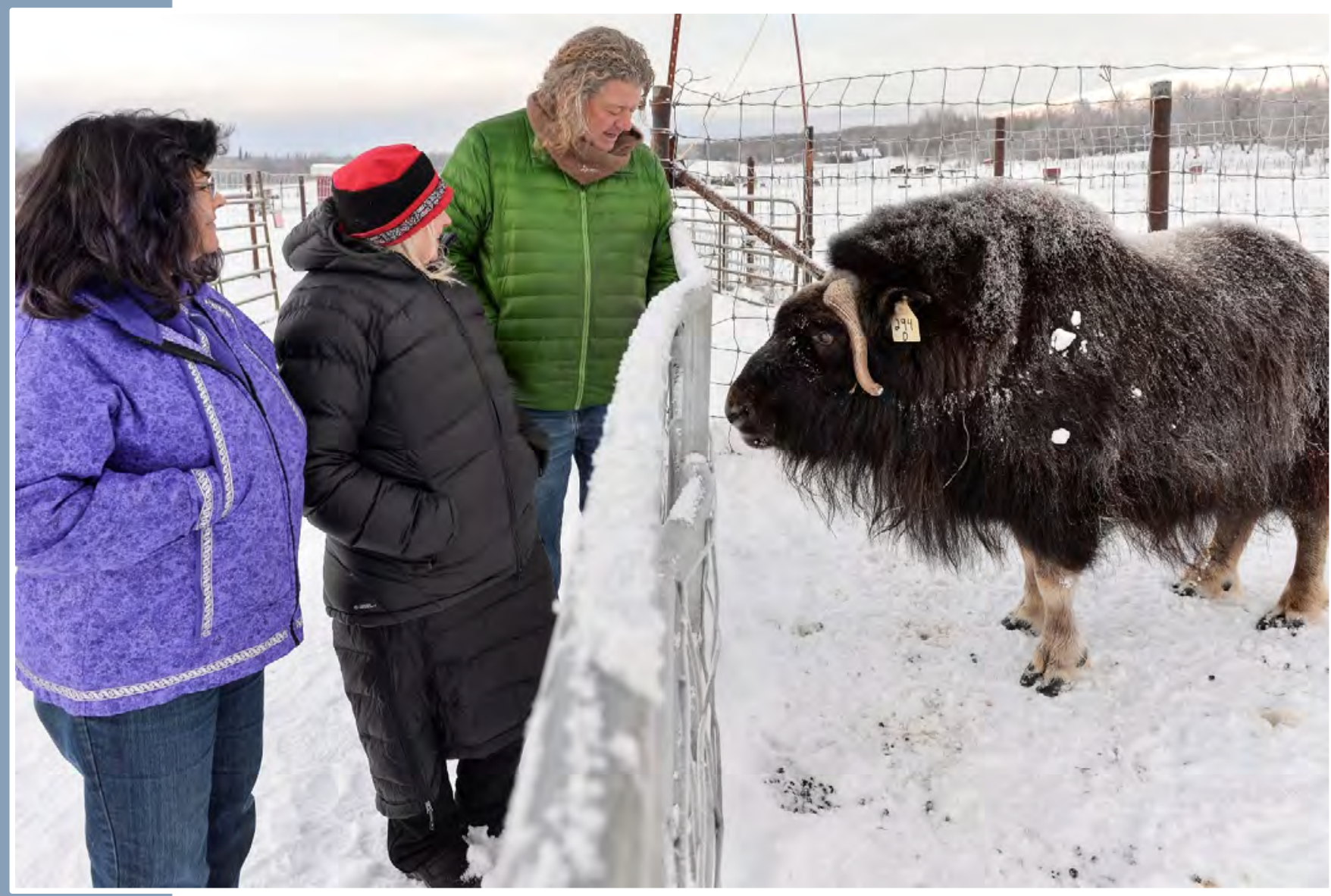

CONTACT

Aisha Bonner Cozad, abonner@aarp.org

For media inquiries, please contact media@aarp.org

This research was designed and executed by AARP Research. 